
$\begin{array}{llllllll}\mathbf{A} & \mathbf{R} & \mathbf{T} & \mathbf{Y} & \mathbf{K} & \mathbf{U} & \mathbf{L} & \mathbf{Y}\end{array}$
$\begin{array}{llllllll}\mathbf{R} & \mathbf{O} & \mathbf{Z} & \mathbf{P} & \mathbf{R} & \mathbf{A} & \mathbf{W} & \mathbf{Y}\end{array}$
Radosław Pawelec
DOI: 10.33896/PorJ.2021.2.1
(Uniwersytet Warszawski, e-mail: r.pawelec@uw.edu.pl)
ORCID: 0000-0003-4739-6471

\title{
WZGARDA, LUDZIE I BÓG. SEMANTYKA SEÓW \\ Z GNIAZDA LEKSYKALNEGO <POGARDA> W ŚREDNIOWIECZU I TWÓRCzOŚCI JANA KOCHANOWSKIEGO
}

W opisie ksiażki Andrzeja Szcześniaka Deportacje XX wieku wydanej w 2002 r. czytamy:

1) Wiek XX, to wiek pogardy i poniżenia człowieka, realizowany pod hasłami „dobra ludzkości"; to wiek masowego ludobójstwa, którego jedna z form były deportacje ludności, połączone $z$ nędzą i poniżeniem godności, $z$ zamykaniem $w$ obozach niewolniczej pracy, z masowymi mordami słabych, którzy nie mieli siły iść dalej.

Co do roli, jaką odegrała pogarda dla drugiego człowieka, całych grup społecznych i narodów w minionym stuleciu, historycy i poeci sa wyjatkowo zgodni. W Traktacie poetyckim Czesław Miłosz pisze o duchu dziejów, który przechadza się, „gdzie wiatr zawiewa dymem $z$ krematorium”:

2) Już go zobaczył i poznał poeta, Gorszego boga, któremu poddany

I czas, i losy jednodniowych królestw. (...)

Kto go nie uzna, dotknięty pałeczka,

Bełkotać zacznie i utraci rozum.

Kto mu się skłoni będzie tylko sługa.

Gardzić nim będzie jego nowy pan [Miłosz 1981, 221].

W wierszu Tadeusza Różewicza Biel historiozoficzność pogardy nabiera charakteru nie tyle związanego ze sztuka, ile $z$ moralnością i religią:

3) związali baranka udusili baranka ze skóry obłupili kości mu policzyli (...) skazali baranka pogardą okryli śmiechem przebili kłamstwem nakarmili [Różewicz 2016, 282]. 
Pogarda jest we współczesnej etyce społecznej stawiana obok nienawiści jako jedna $z$ najważniejszych antywartości. Tych, które w niedalekiej przeszłości doprowadziły do zniszczenia na niespotykaną nigdy wcześniej skalę; tych, co do których niewiadomej przyszłości odnosi się przepowiednia Alberta Camusa o „obudzeniu i posłaniu szczurów, by znów umierały w szczęśliwym mieście”. Jednakże początki znaczeń słów $z$ tego gniazda były zupełnie inne, od strony aksjologicznej i semantycznej pogarda była wpisana w logikę religii chrześcijańskiej i społeczeństwa stanowego, miała swoje miejsce w ustanowionym porządku świata boskich i ludzkich relacji.

W tym tekście znany nam punkt dojścia zestawiamy ze średniowiecznym początkiem i twórczością Jana Kochanowskiego. W ten sposób można dostrzec $z$ jednej strony rozwój pewnych tendencji, $z$ drugiej zaś jednostkowy wymiar wartości, świadomie kształtowanych w języku autora Trenów. Wynik tego jest interesujacy, choć niezaskakujaccy - widać, jak dokonuje się przesunięcie średniowiecznych wartości związanych ze słowami i ich odniesien $-z$ wybitnie religijnych na bliskie nam, ludzkie. Zarazem widać umiejętne wykorzystanie walorów stylistycznych wyrazu i ograniczenia, jakie wybitny twórca nakłada na swój język, by już czysto ludzka pogarda nie kłóciła się $z$ harmonijną etyką jego humanizmu.

\section{ETYMOLOGIA POGARDY \\ I „ROZCIĄGLIWOŚĆ SEMANTYCZNO-AKSJOLOGICZNA” ZWIĄZANYCH Z NIĄ SEÓW W ŚREDNIOWIECZU}

Rzeczownik pogarda, podobnie jak wzgarda, to słowo pochodzące od ogólnosłowiańskiego czasownika gardzić, który zdaniem Wiesława Borysia w języku prasłowiańskim miał postać * grditi, a jego znaczenie odpowiadało peryfrazom 'czynić zarozumiałym, wyniosłym; pogardzać, lekceważyć'. Słowo to pochodziło od przymiotnika *grdъ, mającego podstawowe znaczenie 'ogromny, silny' i cały szereg znaczeń przenośnych: 'wspaniały, majestatyczny, smiały', 'zdajacy sobie sprawę ze swej siły, godności, wyniosły, pyszny, butny', 'budzący grozę, straszny’ [Boryś 2010, 155].

W materiałach $z$ doby staropolskiej nie dochowało się ani jedno użycie rzeczownika pogarda, tylko dwa wgarda, liczniejsze sa użycia rzeczowników odczasownikowych: gardzenie, wzgardzenie, zgardzenie, a najliczniejsze - czasowników i ich wariantów: gardzić, wzgardzać, wzgardzić, pogardzić, wzgardzić, zgardzić.

Ten bogaty zasób leksykalny, nieco odmienny od współczesnego języka przez to, że dominuja w nim czasowniki, wykazuje wcale duże zróżnicowanie semantyczne. Znaczenia leksemów sa wszakże dość łatwe do odczytania dla dzisiejszego odbiorcy, m.in. ze względu na ich pokrewieństwo, wzajemną motywację. Rzecz jest przy tym ciekawa od strony 
aksjologicznej: jak powiedzieliśmy, społeczeństwo średniowieczne było stanowe, hierarchiczne, tak więc wyższość jednych nad drugimi uważano za rzecz naturalna, oczywiste było też jej okazywanie $z$ jednej strony i podporządkowanie się jej $-z$ drugiej, oba zresztą w dwu co najmniej wymiarach, parafrazujac słowa modlitwy: „tak na ziemi, jak i w niebie”. W komunikacji językowej służyły temu m.in. wymienione słowa, cały zaś układ socjologiczno- / religijno-lingwistyczny powodował, że wyrazy owe nie miały równie silnego jak dziś nacechowania, mogły natomiast występować w znaczeniach pochodnych, np. w modlitwie do Stwórcy, by nie gardził ludzka prośba - by jej nie odrzucał, by uznał za godna wysłuchania:

4) Wysłuchaj, Boże, modlitwę moją i nie gardzi (Fl: wzgardzaj) prośbą moją [Pul 54, 1]. ${ }^{1}$

Podobnych cytatów znajdujemy więcej (np. „sercem skruszonym a pokornym nie gardzi Panie Boże" [1448 R XXIV]), ogólnie jest też tak, że - ponieważ znaczna większość przechowanych do naszych czasów przykładów to konteksty biblijne - najczęściej mowa o stosunkach między ludźmi lub człowiekiem a Bogiem. Możliwe kombinacje związane $z$ gardzeniem są tu jednak różne, występują też konteksty, w których gardzić odnosi się do stosunków (tylko) międzyludzkich, a w nich np. do odrzucenia rad i napomnień. Przyjrzyjmy się kontekstom:

5) Dusza, która by zgrzeszyła, a gardząc Bogiem (contempto Domino), zaprzałaby pokładu błysnego swego... nawróci wszystko (...) [BZ Lev 6, 2].

6) Miłosierdzie Twoje na wieki, działa ręku Twoju nie gardzi [Fl 137, 9].

7) Ten to nasz syn niekarany i nieposłuszny jest, napominania naszego słyszeć nie chce i gardzi [BZ Deut 21, 20].

8) Najpierwsze tegda myśl o pokorze, a tać na czworga się ukazuje: nie dbać na ten swiat i nikim nie gardzić (...) [XV med. R XXII 236].

W sytuacji człowieka proszacego Boga o to, by nim nie gardził, można zrozumieć, że chodzi o uznanie ludzkiej godności, ważności w oczach Stwórcy - ewentualne gardzenie wynika tu $z$ wyższości jednej strony nad druga. Rozumowania tego nie można wszakże zastosować w odwrotną stronę, w cytatach (5) i (6) należy przeto zmodyfikować rozumienie słowa: chodzi o to, by nie odrzucać Boga i jego dzieł. Związek z głębokim szacunkiem jest tu oczywisty, aspekt odrzucenia pojawia się jednak na tyle wyraźnie w wielu dawnych użyciach czasownika, że jest godny podkreślenia. Dość podobnie jest w stosunkach międzyludzkich. Syn powinien słuchać rodziców i ich napomnień, a nie gardzić nimi, czyli lekceważyć je, odrzucać bez należytego uszanowania. Ważnym dla chrześcijanina

1 Cytaty przytaczane za słownikami, w tym wypadku - Staropolskim (SStp), sa podane $z$ sygnaturami, którymi sa opatrzone w tych słownikach. 
źródłem takiej postawy jest pokora, jeden $z$ najważniejszych jej aspektów wiąże się $z$ tym, by nikim nie gardzić, o czym poucza cytat (8).

Na tym nie kończy się złożoność pojęcia gardzenia, co widać wyraźnie $\mathrm{w}$ relatywnie liczniejszych użyciach czasowników przedrostkowych $z$ pary aspektowej: wzgardzać / wzgardzić. Pierwszy z nich jest objaśniany w SStp za pomocą dwóch definicji synonimicznych, z których pierwsza, odnosząca się do wszystkich cytatów prócz jednego, jest dużo dłuższa:

1/ gardzić, nie cenić, lekceważyć, też odtrącać, odrzucać, zaniedbywać, brzydzić się, nie zważać (na coś) [plus odpowiedniki łacińskie];

2/ nie chcieć czynić czegoś, odmawiać (...).

Jedyny cytat przypisany do drugiego znaczenia to „Wzgardzała (MamLub 130: nie chciała jest) weselić się (...) dusza moja" [Fl 76, 3]. Prawdopodobnie na wyróżnieniu zaważyła tu możliwość doprecyzowania $\mathrm{w}$ innym wariancie tekstu oraz paralelizm tego znaczenia wobec wyróżnionego w haśle wzgardzić. W zasadzie jednak można byłoby i ten kontekst podciagnąć pod bardzo szeroko zakreślone znaczenie pierwsze. Liczba synonimów składających się na jego eksplikację jest podobna do liczby cytatów, które objaśniaja, średnik sugeruje jednak, że mamy zasadniczo do czynienia $z$ dwoma wariantami semantycznymi, $z$ których pierwszy bardziej odpowiada sytuacji gardzenia $z$ pozycji nadrzędnej, a drugi - podrzędnej albo też odrzucania, odtracania czegoś, odmowy czy zaniedbania. Dobrze ilustruja to cytaty z Psałterza floriańskiego:

9) nie ostawiaj mie ni wzgardzaj mie, Boże, zbawicielu mój [Fl 26, 15].

10) Wszelaka karmią wzgarzała jest dusza jich i przybliżyli są sie aż do wrot śmierci [Fl 106, 18].

Pierwszy jest bardzo podobny do kontekstu (4) przytoczonego na poprzedniej stronie, charakterystyczne jest też to, że czasownik występuje w nim z zaprzeczeniem. Także użycie słowa we fragmencie Psalmu 106 przypomina pod względem znaczenia konteksty (5) i (6), mowa w nim o tym, lud Izraela odrzuca łaskę i pomoc Boska, co doprowadza go do „wrót śmierci”, następnie prosi o pomoc i - po raz kolejny - otrzymuje ja: „I zawołali sa ku Gospodnu (...) posłał słowo swoje i uzdrowił je i wytargł je ze zginienia jich" [Fl 106, 19-20].

Logiczne mogłoby się wydawać, że w większości kontekstów będzie mowa o gardzeniu $z$ pozycji nadrzędnej: pan, szlachcic, król może gardzić swymi poddanymi, Bóg może gardzić grzesznym człowiekiem itd. Analizując cytaty ze słowem wzgardzić (najliczniej reprezentowanym spośród leksemów $z$ tego gniazda w cytatach średniowiecznych), widzimy jednak, że jest odwrotnie: najczęściej mowa o tym, że człowiek wzgardza boskimi prawami, słowem, napomnieniami itp. - co jest oczywiście wartościowane negatywnie - lub też wzgardza innymi ludźmi, jak choćby nieprzyjaciółmi, wreszcie wzgardza czymś, np. bogactwem, skarbami, robota 
- co jest wartościowane bardzo różnie, zależnie od kontekstu. Na wielość tych relacji nakłada się średniowieczna „rozciagliwość semantyczna” czasownika - to źródło bardzo różnorodnych znaczeń kontekstowych:

11) Zginie $z$ ludu swego, bo słowo Boże wzgardził [BZ Num 15, 31].

12) Dziękuję Tobie, Panie Jezu Kryście, któryś dla odkupienia świata... od Żydów wzgardzon [XV ex Kałużn 292].

13) Gospodzin mnie pomocnik jest a wzgardzę nieprzyjacielmi moimi [Pul 117, 7].

14) Tadeus wzgardził wszystki rzeczy i skarby odmówił [Rozm 232].

Wzgardzenie słowem Bożym, o którym mowa w cytacie (11), to świadome naruszenie obowiazku składania Bogu ofiar. Fragment Księgi Liczb, $z$ którego pochodzi ten kontekst, mówi o tym, że popełnia grzech ten lub ci, kto / którzy zaniedbują nieświadomie swe ofiary, możliwe jest jednak jego odpuszczenie po dokonaniu przez kapłana obrzędu przebłagania. Inna jest sytuacja osoby lub osób popełniajacych ten grzech świadomie. Zasługuja na karę „wyłączenia spośród ludu” i „wyłączenia bez miłosierdzia”, obrazili bowiem Boga (tak w Biblii Tysiąclecia). Wzgardzić można tu interpretować zarówno jako 'odrzucić', jak i 'zlekceważyć', zdaniem leksykografów bardziej odpowiednia jest ta druga eksplikacja, o czym dalej.

W wielu cytatach, w których mowa o wzgardzeniu, powtarza się ważny $z$ religijnego punktu widzenia paradoks: otóż Jezus dobrowolnie wydał się na wzgardę Żydów. Przykładem jest cytat (12), jak można uważać, wzgardzon oznacza tutaj nie tylko to, że okazano mu 'brak szacunku', lecz dopuszczono się 'poniżenia go, zszargania jego godności'.

W kolejnym kontekście, Psalmie 117 (w Psałterzu puławskim, w innych źródłach bywa on dołączany do następnego lub poprzedniego psalmu), najlepsza parafraza znaczenia byłoby 'lekceważyć, nie przejmować się, nie czuć zagrożenia' - chodzi bowiem o to, że człowiek bogobojny, któremu Pan pomaga, nie musi bać się nieprzyjaciół. W Biblii Tysiaclecia znajdujemy tu sformułowanie: „Pan ze mną, mój wspomożyciel / ja zaś będę mógł patrzeć z góry na mych wrogów” [Ps 118, 7]. Jeszcze inne jest znaczenie słowa w ostatnim cytacie. Juda Tadeusz po uleczeniu Abagarusa odmówił przyjęcia wszystkiego tego, co wdzięczny król mu proponował - odmówił użyte w tym wyjaśnieniu jest najbliższe znaczenia wzgardził w cytacie.

Nieco podobnie jak poprzednio leksykografowie tę klęskę nadmiaru próbują ująć w definicje synonimiczne. Najbardziej złożona jest przy tym pierwsza $z$ nich, pod która znajdujemy wszystkie powyższe przykłady: 'okazać brak szacunku, zlekceważyć, okazać swoje obrzydzenie, wstręt (...)'. Przytoczona definicja, jakkolwiek szeroka, nie jest wystarczająco pojemna, by objąć całą różnorodność znaczeń słowa pojawiających się w poszczególnych kontekstach.

Jest to przy tym tylko jedna $z$ definicji. W SStp znajdujemy jeszcze dwa inne znaczenia: 'napełnić pycha', odnotowane ze znakiem zapytania i tylko jednym przypisanym do niego cytatem, oraz 'przez lekceważenie 
nie chcieć (czegoś czynić), odmówić'. To drugie zasługuje na uwage, ponieważ jest obszernie ilustrowane, a przy tym najwyraźniej jest składnikiem dawnego języka prawnego. Oto przykłady:

15) $Z$ pilnością jeśm pobudził sąsiady proszac ich aby mi pomogli... złodzieja pogonić. Tedy oni wzgardzili (...) a pomocy dać nie chcieli [Dział 28].

16) Gdyby pozwany dbać nie stał albo wzgardził (...) ośmi skot za winą sądowi ma zapłacić [Sul 64].

Dość trudno jest wskazać jednoznacznie motywację odmowy pewnego działania. To, że sąsiedzi nie ruszyli na pomoc osobie okradanej, może wynikać ze strachu, zadawnionych uraz czy też animozji i wielu innych przyczyn. Leksykografowie, kierujac się zapewne innymi znaczeniami czasownika, wybieraja 'lekceważenie'. Tak czy owak odmowa jest jednak faktem i ten podlega ocenie oraz sankcji moralnej (tudzież może być przedmiotem skargi, czyli żałoby) - jak w pierwszym przykładzie lub też osądowi i karze stricte prawnej - jak w cytacie następnym.

We współczesnych przepisach prawa bez trudu odnajdziemy podobne sformułowania, np. art. 162 par. 1. Kodeksu karnego brzmi:

17) Kto człowiekowi znajdującemu się w położeniu grożącym bezpośrednim niebezpieczeństwem utraty życia albo ciężkiego uszczerbku na zdrowiu nie udziela pomocy, mogąc jej udzielić bez narażenia siebie lub innej osoby na niebezpieczeństwo utraty życia albo ciężkiego uszczerbku na zdrowiu, podlega karze pozbawienia wolności do lat 3 [k.k.].

Współcześnie ustawodawca posługuje się ramą: <kto nie + czasownik>, w średniowieczu używano konstrukcji: < kto by wzgardził, kto wzgardzi... + czasownik lub rzeczownik odczasownikowy>.

Prócz dotąd omówionych słów, mających na ogół co najmniej przeciętna w (zachowanym) materiale średniowiecznym liczbę użyć i mniej lub bardziej rozbudowana strukturę semantyczna, w Słowniku staropolskim znajdujemy konteksty $z$ wieloma innymi wyrazami $z$ tego samego gniazda, należy ono bowiem do dość rozbudowanych. Potwierdzają one dotąd sformułowane uwagi, wśród nich zwłaszcza tę, iż w średniowieczu wzgarda nie miała silnie ani też jednoznacznie negatywnego sensu, a słowa $z$ nia związane wykazywały wielka plastyczność (jak powiedzieliśmy nieco bardziej metaforycznie: „rozciagliwość) semantyczna i aksjologiczna. Tak można było powiedzieć $z$ dezaprobata o dzieciach odrzucających rady rodziców, wszakże można było też tak określić postawę świętego, wyrzekającego się wynagrodzenia w postaci ziemskich dóbr. Użycia, w których jest uczuciem wypełniajacym serce i popychającym do złych czynów, są wyjątkowe. Analiza wskazuje, że humanistyczna twórczość Jana Kochanowskiego przejmuje wiele $z$ tego złożonego dziedzictwa średniowiecza, $z$ jednej strony - łagodzacc jego ostrość, $z$ drugiej - wzbogacając je o nowe elementy. 


\section{WZGARDA DLA USTAW ŚWIETTYCH I RZECZY DOCZESNYCH, URSZULKA, DOBRA MIEOŚĆ I ODRZUCONY KAMIEŃ - TWÓRCZOŚĆ JANA KOCHANOWSKIEGO}

Podobnie jak w średniowieczu i podobnie jak w XVI wieku w twórczości Jana Kochanowskiego słowo pogarda nie występuje. ${ }^{2}$ Znajdujemy natomiast dość liczne użycia innych wyrazów $z$ tego gniazda, mianowicie 17 użyć czasownika wzgardzić i 1 wzgardzać, 18 użyć gardzić, 13 użyć imiesłowu wzgardzony, 3 - rzeczownika wzgardzenie i 21 - wzgarda. Czasownik najczęściej występuje w Psalmach i najczęściej w swym znaczeniu kontekstowo nacechowanym negatywnie, mianowicie odnosi się do sytuacji, gdy ludzie wzgardzaja świętymi ustawami Boga, przymierzem $z$ Bogiem, samym Bogiem lub osadzona w sakralnej aksjologii wartością cnoty, np.:

16) Zakon jego przed oczyma zawdy był memi / Anim wzgardził ustawami jego świętemi [Psalm 18, Kochanowski 1989, 323].

17) W potrzebie tył podali: czemu? bo wzgardzili Przymierzem Pańskim / ani praw posłuszni byli [Psalm 78, Kochanowski 1989, 410].

W cytacie $z$ Psalmu 18 mamy do czynienia $z$ aksjologicznym przeczeniem podwójnym, w tekście zaprezentowany jest wizerunek potęgi Pana i osoba człowieka pobożnego, który oddaje mu cześć, z najwyższym szacunkiem stosując się do boskich praw. Jego postawa jest charakteryzowana wcześniej słowami definiującymi logiczne przeciwieństwo wzgardzenia, oznaczającymi mianowicie wierność Stwórcy i podażanie wskazana przezeń droga: „Bom ja zawżdy świętych Jego dróg naśladował / / A nigdym od Boga swego nie odstępował".

W kolejnym cytacie mowa o klęsce synów Efraima w walce, która to klęska była konsekwencją oporu wobec Boga, niewdzięczności za jego łaskę, niewypełniania swych powinności i postępowania wobec Boga, bez „szczerej, serdecznej chęci”. Tym ostatnim sformułowaniem, zaczerpniętym $z$ definicji w Słowniku wileńskim, parafrazujemy znaczenie słowa uprzejmość, użytego w poprzedzającym kontekście: „Aby nie byli ojcom podobni, spornemu / Narodowi i łaski Pańskiej niewdzięcznemu, / Którzy niedobrze się w swej czuli powinności / Ani postępowali z Bogiem w uprzejmości”. To wszystko składa się na okazaną Bogu wzgardę i jej fatalne następstwo. Ciekawe, że w tym samym Psalmie czasownik użyty jest raz jeszcze, tym razem po to, by nazwać postawę rozgniewanego

2 Por. indeks haseł w Słowniku polszczyzny XVI wieku on-line, http: / spxvi. edu.pl/, dostęp lipiec 2020 r. Hasła z przedrostkiem po- znajdujemy natomiast w słowniku zbierającym materiał językowy z XVII i XVIII wieku, odnotowuje je też Samuel Bogumił Linde, w większości ilustrując cytatami z II połowy XVIII wieku, wszakże występuja też wcześniejsze, np. z pism F. Birkowskiego. Do sprawy tej wracamy dalej. 
Stwórcy: „Pan ... chęć od Izraela wszytkę swą oddalił. Namiotem / i ołtarzmi wzgardził Silońskiemi” [Psalm 78, Kochanowski 1989, 412].

Pośród utworów J. Kochanowskiego należących do literatury świeckiej, w których najczęściej występuje wzgardzić, na szczególną uwage zasługuja zwłaszcza Pieśni i Treny. W obu tych wykwintnych formach poetyckich można spotkać użycia czasownika nawiąujące do kontekstu religijnego (jak wyżej) lub też służące wzmocnieniu przekazu tekstu:

18) Wzgardziłaś mna, dziedziczko moja ucieszona.

Zdałać sie ojca twego barziej uszczuplona

Ojczyzna, niżlibyś ty przestać na niej miała [Tren 3, Kochanowski 1989, 564];

19) Jest kto, co by wzgardziwszy te doczesne rzeczy

Chciał ze mna dobra tylko sławę mieć na pieczy,

A starać sie, ponieważ musi zniszczeć ciało,

Aby imię przynamniej po nas tu zostało? [Pieśń 19, II, Kochanowski 1989, 275];

20) Tę nadzieję mam o tobie,

Że mię też masz za co sobie

Ani wzgardzisz chucia moja,

Ale mi ją oddasz swoją [Pieśń Świętojańska o Sobótce, Kochanowski 1989, 288].

Apostrofę do Urszulki, zawierająca słowa: „Wzgardziłaś mną, dziedziczko moja...", można $z$ jednej strony odczytywać jako stylistyczne wzmocnienie przekazu - przecież o zwykłej wzgardzie tu nie może być mowy, z drugiej zaś jako nawiązanie do żałobnej tradycji, znanej np. jeszcze H. Sienkiewiczowi, w której wypomina się zmarłemu śmierć jako „decyzję” odejścia do lepszego świata. Kobiety w orszaku ze zwłokami Danusi „wołały znów: Źle ci tu było kwiatuszku, z nami - źle? - Ostał się rodzic w wielkiej żałobie, a ty już chodzisz po Boskich pokojach" [Sienkiewicz 2006, 436]. W wersji J. Kochanowskiego upatrywać też można nawiązania do znanych $z$ pewnościa poecie tekstów religijnych, w których święci wzgardzali dobrami doczesnymi dla wartości najwyższych - to postawa np. Tadeusza Judy, przywołana w cytacie (14). Tenże wątek pojawia się następnym cytacie, wzgardzenie doczesnymi rzeczami jest w Pieśni 19 zestawione z dbałością o sławę i dobre imię.

Inny charakter ma wzgardzenie w Pieśni świętojańskiej o Sobótce, pieśń czwartej Panny jest skierowana do ukochanego. Z dzisiejszego punktu widzenia również w tym kontekście można dostrzegać element wzmocnienia, wszak chodzi nie tylko o nieodrzucenie uczucia, ale w istocie o aprobatę, przychylność i wzajemność - jest to wyraźnie sformułowane dalej. Liczne - $\mathrm{i}$ „szersze semantycznie”, bo dające się interpretować też jako 'odmówić' - w średniowieczu użycia o charakterze religijnym nadawały słowu temu specyficznego zabarwienia stylistycznego. W Pieśni świętojańskiej o Sobótce występuja one zreszta obok takich właśnie zupełnie świeckich odniesień, np. wcześniej trzecia Panna śpiewa: „Nie ma w swym szaleństwie miary, / Kto gardzi Pańskiemi dary; / A bodaj miał płakać siła, / Komu dobra myśl niemiła”. 
Możliwość wzgardzania przysługuje tylko ludziom i Bogu - łączliwość imiesłowu podawana przez SPJK to wzgardzony: od / u Pana, świata ludzi, rzemieślników, ludzi, obcych, swych. W języku poety ta ludzko-boska relacja nie tylko jest zwiazana $z$ podmiotem, lecz i przedmiotem: dotyczy w ogromnej większości osób i ich zachowań, a jeśli mowa o Bogu - to jego praw, nakazów, wiary itp. W jednym cytacie, co ciekawe, mowa o tym, że wzgardzona jest część nieożywionej przyrody - kamień. Nawet jednak ten jedyny przypadek odnosi się $\mathrm{w}$ istocie do świata ludzkiego, w Psalmie 118 wraca myśl, jakże znana z Ewangelii wg św. Mateusza, że ostatni będa pierwszymi:

21) Kamień od rzemieślników niedbałych wzgardzony Na kąt czelny jest włożony [Psalm 118, Kochanowski 1989, 469].

Jeżeli porównamy umieszczone w Słowniku języka poety definicje wzgardzić: 'odrzucić, odtrącić kogoś, coś, zlekceważyć, wyrzec się czegoś z pogarda, pogardzić czymś' oraz gardzić 'lekceważąc, mając za nic odtracać, odrzucać', należałoby uznać, że ten drugi wyraz ma nieco mniej zróżnicowana strukturę znaczeń. Analiza cytatów nie prowadzi jednak do odnotowania zasadniczych różnic semantycznych, znajdujemy użycia podobne pod względem kontekstu, np. miłosnego, przy tym majace aspekt perswazyjny - jak niżej cytowane z Odprawy posłów greckich, a także użycia w odniesieniu do artefaktów - jak w cytacie ze słynnej pieśni Serce roście...:

22) Wenus kiedy mie naprzód trzy boginie sobie Za sędziego obrały, Wenus mi ją sama

Najpierw zaleciła i za żonę dała.

Ludzie, widzę, u Boga szczęścia sobie proszą,

A ja, kiedy mie $z$ chęci swej tym potykali,

Miałem gardzić? Przyjałem, i przyjąłem wdzięcznie,

I mam pewną nadzieję, że tenże bóg, który

Ućcił mię naprzód, będzie i do końca szcześcił [Odprawa posłów greckich, Kochanowski 1989, 594].

23) Dobra myśli, której nie przywabi,

Choć kto ściany drogo ujedwabi,

Nie gardź moim chłodnikiem chruścianym;

A bądź ze mną, z trzeźwym i z pijanym! [Pieśń II, Kochanowski 229].

Zauważyć natomiast można, że czasownik gardzić jest statystycznie nieco częstszy w pismach „świeckich” niż w Psalmach (wzgardzić w Psalmach występuje 8 razy, a wszystkie użycia to 17; gardzić w Psalmach 6 razy, a wszystkie użycia - 18). Także użycia gardzić zwiazane $z$ czysto ludzkimi sprawami są wyrazistsze niż poprzednio, np.: 
24) „Pij ty, włódarzu, i mów, coć się będzie zdało, Prosto, jako za naszych ojców więc bywało!" „Takci bywało, panie, pijaliśmy z soba, Ani gardził pan kmiotka swojego osobą; Dziś wszytko już inaczej, wszytko spoważniało; Jako mówią: postawy dosyć, wątku mało [Przymówka chłopska, Kochanowski 1989, 224].

Ostatni cytat odnosi się do stosunków społecznych i brzmi dość znajomo - podobne konteksty znajdziemy bez trudu np. w wielkiej literaturze realistycznej XIX wieku, dziełach $z$ czasów zmierzchu społeczeństwa stanowego i demokratyzacji struktury społecznej (np. w Lalce: „Furmani zaś powozów najętych trzymali się blisko siebie, gardzący resztą i przez nia pogardzani" [Prus, I 50], w tejże powieści szczególnie często słowa $z$ gniazda <pogardy> padaja $\mathrm{w}$ aspekcie relacji między Izabela Łęcką a Stanisławem Wokulskim).

Najciekawszy chyba i najbardziej wyrazisty obraz przesunięcia uczuć ze świata religii do świata stosunków międzyludzkich jest widoczny na przykładzie rzeczownika wzgarda. Jak powiedzieliśmy, J. Kochanowski nie posługiwał się derywatem pogarda, względnie często (w gnieździe jest to słowo o najwyższej frekwencji - 21) używał natomiast rzeczownika wzgarda, któremu autorzy hasła w słowniku jego języka przypisują znaczenie: 'brak szacunku, pełen lekceważenia stosunek do kogoś albo do tego, co ten ktoś robi, mówi, myśli, też objawy tego lekceważącego stosunku, np. pogardliwe, obraźliwe słowa'. W definicji tej następuje przesunięcie akcentów $z$ typowego dla dawnych kontekstów religijnych podporządkowania w stronę braku szacunku, w efekcie niewiele różni się od współczesnej, np. w dostępnym on-line Słowniku języka polskiego $P W N$ wzgarda to 'stosunek do kogoś polegający na braku szacunku do niego, na niskiej, lekceważącej ocenie'.

Biorąc pod uwagę, że wzgarda J. Kochanowskiego ma bliski współczesnemu sens, $z$ tym większym zaskoczeniem odnotowujemy fakt, że rzeczownik ten występuje tylko w tłumaczeniach psalmów. Podczas lektury stwierdzamy wszakże, że w tym $z$ natury niejako religijnym tekście odniesienia wzgardy dotycza głównie relacji międzyludzkich (oczywiście na tyle, na ile to możliwe, wszak prezentowana w tych utworach rzeczywistość jest inspirowana duchem Stwórcy i wolą Boską):

25) Na pany wzgarda przyszła, że się kryć musieli, A z pustych lasów wyźrzeć nie śmieli (...) [Psalm 107, Kochanowski 1989, 457].

26) Wzgardę zewsząd odnosim, szyderstwa cierpimy, Prawie wszytkim na końcu języka siedzimy [Psalm 44, Kochanowski 1989, 363].

27) Bodaj za moje wzgardę obelżenie mieli, Którzy mi mówią: „Tegośmy chcieli” [Psalm 40, Kochanowski 1989, 358]. 
Wzgarda, która „przyszła na pany” w Psalmie 107, jest rezultatem utraty boskiej laski (przelanej na „ubogiego"), jej konsekwencje jednak ujawniaja się w świecie ludzkim: relacjach społecznych i drastycznym pogorszeniu warunków życiowych. Dość podobnie w Psalmie 44, w którym uwagę zwraca (powyżej w części zacytowany) fragment mówiący o jakże istotnym językowym aspekcie bycia wzgardzonym: o szyderstwach, obmawianiu i wyśmiewaniu. Wrażliwość poety na kwestie komunikacyjne zwiąane $z$ okazywaniem wzgardy widać także w Psalmie 40. Można sadzić: że „tegośmy chcieli” jest wyrazem złych życzeń ze strony innych ludzi. We współczesnych tłumaczeniach tekstu mowa o wyśmiewaniu: „Niech osłupieją hańbą okryci, którzy mi mówią: "Ha, ha!»" [Biblia Tysiaclecia] lub cieszeniu się $z$ cudzego nieszczęścia: „Niech w pohańbieniu odejda / cieszacy się z moich nieszczęść" [Biblia warszawsko-praska]. Jak widać, w różnych wariantach znaczeniowych występuje w tych tekstach utrata szacunku, tłumacze XX-wieczni ewokuja to słowem hańba, Jan Kochanowski posłużył się zaś wzgardą. Tak czy owak rzecz przenosi się w zwykły ludzki, socjologiczny wymiar, a w tekście, choć brzmi jeszcze w nim starotestamentowa srogość, odczytujemy znaczenie bliskie eksplikacji z II połowy XIX wieku [SWil]: 'uczucie, za którym idac, sądzimy, że osoba lub rzecz nie jest warta szacunku, względu, uwagi; oraz objaw tego uczucia, gardzenie, wzgardliwość'.

\section{3. „DUSZE W POGARDZIE WLEC I SZYDERSTWAMI SIEC” - DYNAMIKA ROZWOJU SEMANTYCZNEGO LEKSEMÓW Z GNIAZDA < POGARDY> W KOLEJNYCH WIEKACH}

W kartotece Słownika polszczyzny XVI wieku odnotowano ponad 200 użyć słowa wzgarda, ponad 600 wzgardzić, dużą frekwencję mają także niektóre $z$ innych, licznych derywatów $z$ tego gniazda. Analiza tak obszernego materiału wymaga osobnego studium, w tym miejscu nie jest zreszta potrzebna, gdyż wszystko wskazuje na to, że widoczna u J. Kochanowskiego tendencja do przesunięcia ich odniesienia ze sfery boskiej do ludzkiej postępuje w kolejnych wiekach, sens zaś owych słów coraz wyraźniej konkretyzuje się wokół wartości negatywnych związanych $z$ brakiem szacunku. Do XIX wieku jest to wszakże proces powolny i jeszcze S.B. Linde w zasadzie nie formułuje analitycznej definicji pogardy i wzgardy (ujmuje je jako synonimy, wzgardzić definiuje 'nie ważyć sobie'). Pierwszą wyrazistą eksplikację znajdujemy w Słowniku wileńskim - jest przytoczona w zakończeniu poprzedniego punktu.

Rozważając późniejszą ewolucję semantyczną i aksjologiczną słów $z$ gniazda <pogardy> w aspekcie przeprowadzonej wyżej analizy, trzeba wskazać co najmniej dwa istotne fakty. Pierwszy odnosi się do Jana Kochanowskiego. Otóż widać wyraźnie, jak poeta z Czarnolasu łączy elementy semantyczne ze średniowiecza $z$ prąami humanistycznymi, 
w rezultacie słowa te zachowuja swą różnorodność, plastykę znaczeniowa, a zarazem często występuja w unikatowej stylistyce: „Wzgardziłaś mną dziedziczko moja ucieszona".

Połączenie światów w pojęciu pogardy, już jako nie tylko bosko-ludzkie, ale raczej diabelsko-ludzkie odniesienie, wraca później w wielkiej polskiej poezji. Np. w Dziadach nad łożem Senatora tak mówi Belzebub do swych „podwładnych”:

28) Możesz na duszę wpaść,

Możesz ją w pychę wzdąć,

A potém w hańbę pchnąc;

Możesz w pogardzie wlec,

I szyderstwami siec:

Ale o piekle cyt!

My lećmy - fit, fit, fit [Mickiewicz 1984, 90].

W stylistyce Jana Kochanowskiego nie mieści się natomiast to, co już wcześniej, a zwłaszcza później, dość było (i jest do dziś) częste w użyciach pogardy: takie jej połączenie $z$ wartościa negatywna, że całość buduje wysoką wartość dodatnią. Chodzi o pogardę śmierci, ran, cierpienia, przypisywaną żołnierzom, patriotom, bojownikom o jakąs sprawę. Tego typu konteksty znajdziemy także w minionych wiekach, wśród cytatów przytaczanych przez S.B. Lindego sa również takie: „Scewola, pogardziciel i nieprzyjaciól, i płomieni” [Birk. Krz. K. 23 Birk. Dom. 85].

Drugi fakt odnosi się do aspektu aksjologicznego pogardy / wzgardy. W średniowieczu i renesansie jest mianowicie tak, że trudno byłoby ją jednoznacznie przyporządkować do antywartości. Wyraźnie ujemna jest tylko w tym wypadku, gdy ludzie gardza prawami ustanowionymi przez Boga, gdy natomiast mowa o stosunkach między nimi, rzecz staje się niejednoznaczna. $Z$ jednej strony, dlatego że pojęcie było rozciagliwe i zgoła nie to samo co dziś, $z$ drugiej - w społeczeństwie stanowym wyższość jednych nad drugimi stanowiła element porządku socjalnego i doprawdy trudno wyobrazić sobie, by ktoś wymagał od rycerza szacunku dla córki karczmarza czy parobka sąsiada.

Rzecz zmienia się diametralnie w momencie demokratyzacji społeczeństwa oraz zawężenia i „wyostrzenia” pojęcia. Od wielu dziesięcioleci słyszymy o prawach człowieka, przyrodzonej godności osoby ludzkiej itp. - to jest coś, co współcześnie nie podlega żadnej dyskusji, tego typu poglądy łączą zwolenników lewicy z moralistami związanymi z Kościołem. Zapewne są one też rezultatem świadomości tego, co było następstwem kolejnego kroku „na drodze pogardy”: przesunięcia jej znaczenia $z$ braku szacunku na mordercze w swym wymiarze jego zaprzeczenie i odniesienie tegoż już nie tylko do relacji wewnątrzspołecznych, ale do całych narodów i ras. Claus Schenk, hrabia von Stauffenberg, w liście wysłanym jesienia 1939 r. do żony z podbijanych ziem polskich pisze, że „ta ludność jest niewiarygodnym motłochem” („unglaublicher Pöbel”), że to 
„Naród, który dobrze się czuje tylko pod knutem” („Ein Volk, welches sich nur unter der Knute wohlfühlt”) i że „tysiące jeńców dobrze zrobią niemieckiej gospodarce rolnej” („Die Tausenden von Gefangenen werden unserer Landwirtschaft recht gut tun") [cyt. za Winkler 2007, 103].

Słowo pogarda w tym znanym kontekście nie pada. Stosując dość przewrotne rozumowanie, można jednak widzieć w tym pewien sens pozytywny. Wiele wskazuje na to, że przekształcenia semantyczne, które się w nim i zwiazanych $z$ nim wyrazach dokonały, miały swe źródło $\mathrm{w}$ zmianie świata i odzwierciedlały związane $z$ nimi zagrożenia. Tak jak w średniowieczu mówiono o wzgardzie, by porządkować świat społeczny lub napominać religijnie, tak jak J. Kochanowski wyzyskał walory stylistyczne owych leksemów w swej humanistycznej twórczości, tak nam i poetom naszych czasów $-\mathrm{Cz}$. Miłoszowi i T. Różewiczowi - mówienie o pogardzie daje niezbędną do obrony możność nazwania zła, wskazania przeciwnika.

\section{Bibliografia}

W. Boryś, 2005, Słownik etymologiczny języka polskiego, Kraków [SeBo].

S. Dubisz (red. nauk.), 2003, Uniwersalny słownik języka polskiego, Warszawa [USJP].

Elektroniczny słownik języka polskiego XVII i XVIII wieku, sxvii.pl, dostęp: maj $2019 \mathrm{r}$.

S.B. Linde, 1807-1814, Słownik języka polskiego, t. 1-6, Warszawa (przedruk Warszawa 1951).

J. Kochanowski, 1989, Dzieła polskie, oprac. J. Krzyżanowski, Warszawa.

Kodeks karny - Ustawa z dnia 6 czerwca 1997 r. - Kodeks karny, Dz. U. 1997 nr 88, poz. 553 (k.k.)

A. Mickiewicz, 1984, Dziady cz. III, Warszawa.

M. Kucała (red.), 1994-1998, Słownik polszczyzny Jana Kochanowskiego, t. 1-2, Kraków [SPJK].

M.R. Mayenowa (red.), 1966-2001, Stownik polszczyzny XVI wieku, t. 1-36, Wrocław-Warszawa-Kraków [SXVI]; obejmuje także wersję elektroniczna ze wszystkimi dostępnymi na stronie spxvi.edu.pl funkcjami i możliwościami przeszukiwania materiału.

Cz. Miłosz, 1981, Poezje, Warszawa.

B. Prus, Lalka, WolneLektury.pl, dostęp: lipiec 2020 r.

M. Orgelbrand (red.), 1861, Słownik języka polskiego, t. 1-2, Wilno - Słownik wileński (SWil).

T. Różewicz, 2016, Wybór poezji, wstęp i opracowanie A. Skrendo, Wrocław.

H. Sienkiewicz, 2006, Krzyżacy, Kraków.

A. Szcześniak, 2002, Deportacje XX wieku, Warszawa.

S. Urbańczyk (red.), 1953-2002, Słownik staropolski, t. 1-11, Wrocław-Warszawa-Kraków [SStp].

H.A. Winkler, 2000, Der lange Weg nach Westen..., t. 2, Monachium. 


\section{Contempt, humans, and God. \\ The semantics of the words from the lexical nest <pogarda> (contempt) in the Middle Ages and in Jan Kochanowski's works}

\section{Summary}

In the Middle Ages, words from the nest 'pogarda' (contempt) are characterised by semantic and axiological diversity. They can be found in religious texts in requests addressed to God for not rejecting a man or in negative evaluations of the human disregard for God's commands and rules. With respect to interpersonal relations, they mean that one person disregards another one, rejects or refuses to help him or her. The latter might have had legal consequences if the person was obliged to provide such help. In Jan Kochanowski's works, the meanings of such words do not change significantly; first of all, they are specified in their humane dimension in the human world and the stylistic use of their religious markedness is also noticeable. A further semantic evolution goes in the direction of "sharpening" the negative sense of the lexemes, which involves, among others, a change of ethics in the democratic society, where every human being is entitled to equal respect.

Keywords: history of language - semantics - lexicology - axiolinguistics - artistic language - Jan Kochanowski

Trans. Monika Czarnecka 